〈論文〉

\title{
直鎖アルキルベンゼンスルホン酸笽（LAS）の河川・湖沼水中 懸濁物への吸着特性の变化と光の要因について
}

$\begin{array}{lllll}\text { 天 } & \text { 野 耕 二* } & \text { 福 島 武 彦* } \\ \text { 稲 葉 } & \text { 穂* } & \text { 中 杉 修 身* }\end{array}$

\section{Adsorption of Linear Alkylbenzenesulfonates with the Suspended Solids in Natural Aquatic Systems}

\author{
Koji AMANO*, Takehiko FUKUSHIMA*, Kazuho INABA* and Osami NAKASUGI* \\ * The National Institute for Environmental Studies, Onogawa 16-2, Tsukuba, Ibaraki, 305 Japan
}

\begin{abstract}
Distribution of linear alkylbenzenesulfonates(LAS) between the dissolved and adsorbed phase was examined as one of the most important processes in the fate model of LAS in aquatic systems.

Adsorption experiments using solid and sediment taken from a river and lake were performed between $0.3 \sim 9 \mathrm{ppm}$ of the initial solution concentrations of LAS. Coefficient $k$ in the Freundlich isotherm equation $\left(Q=k c^{1 / n}\right)$ varied by nearly 1 order of magnitude. This was due to the fact that not only alkyl chain length and phenyl position, but also the fractional organic carbon content of the suspended solids, the concentration of the suspended solids, and the fraction of each LAS isomer were varied.

The experimental equation used to estimate the Freundlich coefficient $k$ of each LAS homologue $\left(\mathrm{C}_{12} \sim \mathrm{C}_{14}\right)$ and isomer $(2 \phi, 3 \phi, 4 \phi, 5 \sim 7 \phi)$ was verified by using adsorption data from field observations. Values of the observed $k$ in the river and lake were obtained by the field observations using the Freundlich isotherm equation $(n=1.75)$. Freundlich coefficient $k$ of LAS in natural aquatic systems was estimated reasonably (correlation coefficient was between 0.63 $\sim 0.87$.
\end{abstract}

Key words : LAS, adsorption, suspended solid, sediment

\section{1.はじめに}

合成有機化合物による水環境の污染の問題は新たな 環境問題として注目されている。環境中に流出してい る合成有機化合物の種類は数万種あるいは数十万種々 も推定されているが，工場等で使用されている特定の 物質や農地から流出する農薬などの負荷の発生が時期 的・場所的に限られているのに対して, 合成洗剤によ
る污染は年間を通じて全国的に進行する可能性があ る。合成洗剤の主成分である界面活性剤は, 非イオン 性のものの割合も増えているが，LAS（直鎖アルキル ベンゼンスルホン酸塩) に代表される陰イオン性のも のが現在も約半分を占めている1)。LAS は易分解性と はい光, 生物や底質への残留・濃縮性があり, 他の化 合物や重金属との相互作用で毒性を増大させたり，生 体への吸収を促進するといった補助的な役割をるつ可

* 国立公害研究所 テ305 茨城県つくば市小野川16-2 
能性も指摘されている2)。標準的な活性污泥法により LAS は生分解を受けて消失するが, 下水道の普及が立 ち後れている現在, 生活雑排水負荷の大きい人口密集 地域を集水域にもつ多くの河川・湖沼ではLASによ る污染の問題は未だ深刻である。

排水口から水路, 河川, 河口域を経て湖沼あるいは 海域に到るまでに，水中の LAS は好気的な条件で生 分解を受けて消失していくと同時に, 懸濁物質への吸 着を通して底質に移行・蓄積する。LAS が水中では極 く微量あるいは未検出であった河川や湖沼でも, 底質 中には高濃度の LAS が検出された報告3) あり, 水中 の懸濁物質や底質への吸着は水環境中の LAS の運命 を考觉る上で重要な要素である。LAS の吸着について は，限られた条件の室内実験による検討4) 12)がなされ ているが，様々な条件をもつ現場の水域に打ける吸着 特性の変化々その要因についての定量的な解析は, 䚾 とんどなされていない。LAS は疎水基と親水基をあわ せもつ界面活性物質であり, 土䁃や底質への吸着に関 しては農薬などの疎水性化合物と共通した性質をるつ と予想される。このような疎水性化合物の吸着に影響 を及ぼす外的要因に関する知見 ${ }^{13)}$ 16) もあるが，河川・ 湖沼等実際の水環境中にまでは応用されていない。そ こで, 本研究では現場の河川・湖沼水中の溶存態と懸 濁物吸着態の間の LAS の分配を推定することを目的 として, 実験データと現地データに基づいて, LAS の 吸着特性の変化とその要因について考察を行った。

\section{2 . 既往の研究}

LAS の吸着については, 吸着媒として粘土鉱物, 下 水污泥, 河川底質, 河川水中懸濁物などを用いた吸着 実験 ${ }^{4)}$ 12) が行われている。しかし, 溶質中の吸着媒濃 度が数千～数万 $\mathrm{mg} \cdot l^{-1}$, 溶存 LAS の初期濃度が $10 \sim 1,000 \mathrm{mg} ・ l^{-1}$ の条件で行われたものが多く, 実際 の河川・湖沼水中の条件を再現したものにはなってい ない。

これまでの知見では, LAS の吸着は Freundlich の 等温吸着式

$$
\begin{aligned}
& Q=k C^{1 / n} \\
& \text { ただし, } Q \text { : 吸着濃度 }\left(\mathrm{mg} \cdot \mathrm{g}^{-1}\right) \\
& C \text { : 溶存濃度 }\left(\mathrm{mg} \cdot l^{-1}\right) \\
& k, n \text { : 定数 }
\end{aligned}
$$

に従うとされている。多くの実験から求めた $n$ の值が 1.0 2.0 と安定しているのに対して, $k$ の值は 2 オー ダー程度のばらつきを示している77

吸着に影響する要因としては，LAS の同族体・異性 体による吸着量の違いを報告したものが多く，長鎖同 族体注ど，また外部位置異性体ほど吸着しやすいとさ
れている(4),6),10) 12)。高田ら ${ }^{17)}$ は多摩川の水中懸濁物に 吸着している LAS 濃度の測定から現地データについ ても同様の結果を報告している。Hand ら ${ }^{11}$ は同族体・ 異性体による吸着量の違いをアルキル基の疎水性の強 さで説明し，各同族体・異性体ごとにオクタノール/水 分配係数との関係を指摘している。

その他の要因については，吉村ら ${ }^{6)}$ が $5 \sim 30^{\circ} \mathrm{C}$ の範 囲で温度による吸着の差はなかったことに加えて, 溶 液中の $\mathrm{pH}$ が 6 以下の酸性領域で吸着量が増加する傾 向があったことも報告しているが，山本ら ${ }^{5)} は$ 逆にア ルカリ性領域で ABS の吸着量が増大する結果を得て いる。

一方, 有機物一般の吸着については線型吸着等温式 にあてはめて, 吸着相と溶存相の間の分配を論じたも のが多い。Freundlich の等温吸着式で, 定数 $n=1$ の 場合, 吸着濃度と溶存濃度の関係は線型となり,

$$
Q=K_{p} C
$$

という平衡吸着式が成り立つ。Karickhoff $ら^{13)}$ は, 分 配係数 $K_{p}$ が吸着媒粒子の有機炭素含量 $f_{o c}$ と比例関係 にあり，これで補正した分配係数

$$
K_{o c}=K_{p} / f_{o c}
$$

を定義している。ここでは， $K_{o c}$ は吸着媒の特性によら ず吸着質の疎水性のみで決定できるものとして, 吸着 質である化合物のオクタノール/水分配係数 $K_{o w}$ の関 数になるとされている。

$$
K_{o c}=F\left(K_{o w}\right)
$$

また, O'Connor ら ${ }^{14)}$ は分配係数 $K_{p}$ が吸着媒の有機 炭素含量だけでなく溶液中の吸着媒濃度にも影響され ることを指摘している。この理由としては, Gschwend ら ${ }^{18)}$ が懸濁物濃度の増加に伴って, 沪過や遠心分離な どでは分離できない微粒子の濃度も増加し，これらの 粒子に吸着した成分が溶存態として測定され， みかけ の分配係数が減少するためとしている。これらの知見 を受けて, Voice ら ${ }^{15)} K_{p}$ に対するオクタノール/水 分配係数, 吸着媒濃度, 吸着媒の有機炭素含量の 3 変 数による非線形回帰式を統計的に求めている。

$$
K_{p}=F\left(K_{o w}, S, f_{o c}\right)
$$

\section{ただし， $S$ : 吸着媒濃度 $\left(\mathrm{mg} \cdot l^{-1}\right)$}

その他として, Crittenden ら ${ }^{199}$ は活性炭による水中 有機成分の吸着除去の際に複数の成分の競合効果のた めに, 単一成分の場合に比べて吸着量が低下すること を報告している。

Freundlich 式はあくまで経験式であり， $k$ の值をそ のをま用いて一般的な議論をすることは適当ではない が, 本研究では, 室内実験および現地調査で得られた データの範囲で(1)式にあてはめたときの $k$ の值（す なわち, 溶存 LAS 濃度 $1 \mathrm{mg} \cdot l^{-1}$ に招ける平衡吸着 
LAS 濃度) の変動について検討した。 $k$ の変動を説明 する要因としては，吸着質である LAS の同族体・異性 体ごとに異なる疎水性, 吸着媒である懸濁物質の有機 炭素含量と懸濁物の濃度, さらにLAS の同族体・異性 体相互の競合吸着の効果について検討した。

\section{3、調査および実験方法}

\section{1 現地調査おょび試料}

千葉県の大堀川の下流地点 (st: 1), 手賀沼の上流地 点 (st. 2), 大津川の下流地点 (st. 3) に扔いて, 1987 年 4 月より1988年 3 月まで月 1 回の採水を行い, 懸濁 物濃度, 懸濁物中の有機炭素含量, 溶存態々吸着態の LAS 濃度を測定した。Fig. 1 亿調査地点を示す。大堀 川と大津川は手賀沼の流入河川であり, 流域の大部分 が住宅地域で，流入負荷の約 8 割が生活系である ${ }^{20)}$ 。

LAS 分析用の試水は採水後直ちに $2 \%$ の濃度とな るように特級のホルマリンを加えて生分解を抑兑, 実 験室に持ち帰った後 $\mathrm{GF} / \mathrm{C}$ 沪紙（平均保持能力 1.2 $\mu \mathrm{m})$ で吸引沪過して懸濁物を分離し, 溶存 LAS 濃度 と吸着 LAS 濃度を測定した。標準 LAS 溶液を用いた 確認試験の結果, 溶存 LAS は沪紙には吸着しなかっ た。

また，1988年 6 月 22 日に st. 2 打よび st. 3 で大量に 採水し, 遠心分離 $(3,000 \mathrm{rpm}, 40 \mathrm{~min}$.) に上り濃縮し た試水を凍結乾燥して得られた水中懸濁物 (lake solids, river solids）と, 同日 st. 2 で採取し凍結乾燥 して得られた表層 $(0 \sim 2 \mathrm{~cm})$ 底質 (lake sediments) をLAS 吸着実験の吸着媒として用いた。

\section{2 吸着実験}

$\mathrm{C}_{12}$ 体, $\mathrm{C}_{13}$ 体, $\mathrm{C}_{14}$ 体の標準 LAS(花王石鹼株式会社 より提供, いずれも異性体混合物）を用いて, 吸着媒 の種類, 吸着媒濃度, 混合 LAS の同族体組成, 温度, 水中の電解質濃度などの因子を変化させた吸着実験を 行った。各実験（run 1 run16）の条件を Table 1 に

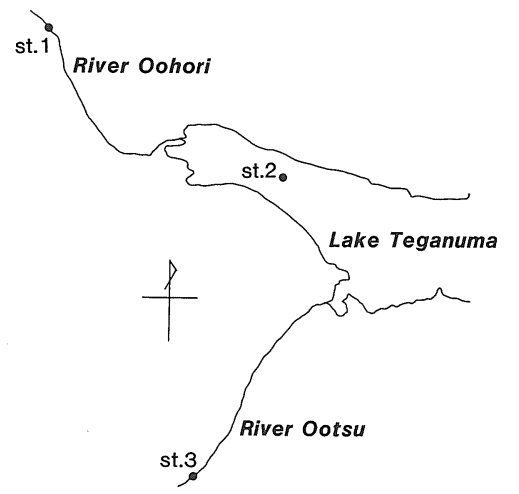

Fig. 1 Locations of the sampling sites.
示す。

予備実験で懸濁物への LAS の吸着が 30 分から 1 時 間で吸着平衡に達することが確認されたため, 純水と 吸着媒 (lake sediments, lake solids, river solids) と 標準 LAS の混合物を所定の濃度に調整した上で恒温 室内のビーカーで $2 \sim 3$ 時間攪找した後, GF/C 沪紙 で吸引沪過して懸濁物を分離し, 溶存 LAS 濃度と吸 着 LAS 濃度を測定した。分解による消失やビーカー 等ガラス器具への吸着によるLAS の実験中に打ける 損失については, 吸着媒（懸濁物, 底質) に元々吸着 していたLAS 濃度と初期濃度から, 吸着実験後の LAS の回収率を計算して確認した。16通りの実験条件 ごとに 4 通りの初期 LAS 濃度 $\left(\mathrm{C}_{12} \sim \mathrm{C}_{14}\right.$ 体合計で 0.3 , $\left.0.9,3.0,9.0 \mathrm{mg} \cdot l^{-1}\right)$ で吸着実験を行った結果, 全 64 ケースで平均 93.9 ( \pm 50.1$) \%$ の回収率 $\left(\mathrm{C}_{12} \sim \mathrm{C}_{14}\right.$ 体 合計）が得られた。

実験結果はすべて Freundlich 式にあてはめて,一条 件につき 4 点からなる等温吸着線と, 最小自乗法によ り計算した $k$ の值を用いて考察を行った。

\subsection{LAS の分析方法}

現地調査のサンプルについては $\mathrm{C}_{11}$ 体〜 $\mathrm{C}_{14}$ 体 LAS をすでに報告した方法 ${ }^{21)}$ で各々異性体別に定量した が, 吸着実験では $\mathrm{C}_{11}$ 体は用いなかったため, HPLCの 条件を若干变更して $\mathrm{C}_{12} \sim \mathrm{C}_{14}$ 体のみを異性体別に迅 速に定量した。

いずれの場合もサンプルの前処理方法は同じであ る。すなわち, 溶存 LAS については試水に $0.2 \mathrm{~mol} ・ l^{-1}$ となるように塩化カリウムを加えた後メチルイソブチ ルケトン (MIBK) に抽出し, MIBK 相に同量の純水 と 5 倍量の $\mathrm{n}$-ヘキサンを加光て水相に逆抽出した試 料をHPLC (装置: 島津 LC4A; 検出器: 島津 SPD2A, UV222nm ; カラム: Shimpack CLC-ODS $6 \mathrm{~mm} \times 150 \mathrm{~mm}$; 溶離液: $\mathrm{CH}_{3} \mathrm{CN} /\left(0.02 \mathrm{M}-\mathrm{NaClO}_{4}\right)$ $\mathrm{H}_{2} \mathrm{O}, \mathrm{C}_{11} \sim \mathrm{C}_{14}$ 体測定の場合は50/50 80/20グラジェ

Table 1 Conditions of the adsorption experiments.

\begin{tabular}{|c|c|c|c|c|c|c|c|c|c|}
\hline \multicolumn{2}{|c|}{ adsorbent } & \multirow{2}{*}{$\begin{array}{c}\begin{array}{c}\text { concentration } \\
\text { of adsorbent } \\
\left(\mathrm{mg} \cdot 1^{-1}\right)\end{array} \\
100\end{array}$} & \multirow{2}{*}{$\begin{array}{c}\begin{array}{c}\text { temperature } \\
{ }^{\circ} \mathrm{C}\end{array} \\
25\end{array}$} & \multirow{2}{*}{$\begin{array}{c}\begin{array}{c}\text { concentration } \\
\text { of KCI } \\
\left.\text { (mg. } 1^{-1}\right)\end{array} \\
0\end{array}$} & \multicolumn{5}{|c|}{$\begin{array}{c}\text { fraction of } \\
\text { LAS homologues } \\
C_{12}: C_{13}: C_{14}\end{array}$} \\
\hline run1 & $\mathrm{A}^{* / 6}$ & & & & 1 & $:$ & 1 & & \\
\hline run2 & $\mathrm{B}^{* *+16}$ & 100 & 25 & 0 & & : & 1 & & \\
\hline run3 & 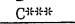 & 100 & 25 & 0 & 1 & : & 1 & $:$ & \\
\hline run4 & $\mathrm{A}$ & 10 & 25 & 0 & 1 & $:$ & 1 & $:$ & \\
\hline run5 & A & 50 & 25 & 0 & 1 & : & 1 & & \\
\hline runl & A & 100 & 25 & 0 & 1 & : & 1 & & 1 \\
\hline run6 & A & 1000 & 25 & 0 & 1 & $:$ & 1 & $:$ & 1 \\
\hline run7 & A & 100 & 25 & 0 & 0 & $:$ & 1 & $:$ & \\
\hline run8 & $\mathrm{A}$ & 100 & 25 & 0 & 1 & $\vdots$ & 4 & : & 1 \\
\hline run1 & A & 100 & 25 & 0 & 1 & : & 1 & : & 1 \\
\hline rung & A & 100 & 25 & 0 & 4 & : & 1 & : & \\
\hline run10 & A & 100 & 25 & 0 & 1 & : & 0 & : & \\
\hline run11 & A & 1000 & 5 & 0 & 1 & $:$ & 1 & & 1 \\
\hline run12 & A & 1000 & 10 & 0 & i & $\vdots$ & 1 & : & 1 \\
\hline run13 & A & 1000 & 25 & 0 & 1 & $:$ & 1 & $:$ & 1 \\
\hline run13 & A & 1000 & 25 & 0 & 1 & $:$ & 1 & & \\
\hline run14 & A & 1000 & 25 & 100 & 1 & : & 1 & : & 1 \\
\hline $\begin{array}{l}\text { run15 } \\
\text { run }\end{array}$ & A & 1000 & 25 & 200 & 1 & : & 1 & & 1 \\
\hline run16 & A & 1000 & 25 & 500 & 1 & $\vdots$ & 1 & $:$ & \\
\hline
\end{tabular}


Table 2 Results of the field observations through one year, including the range of the five items.

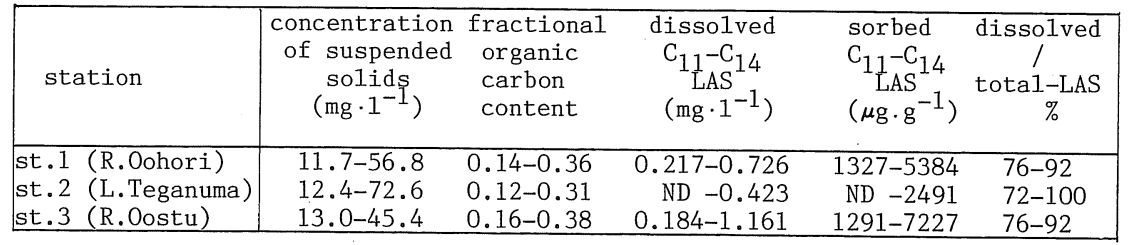

ント溶出, $\mathrm{C}_{12} \sim \mathrm{C}_{14}$ 体のみ測定の場合は65/35固定；流 速 : $\mathrm{C}_{11} \sim \mathrm{C}_{14}$ 体測定の場合は $1 \mathrm{ml} \cdot \mathrm{min}^{-1}, \mathrm{C}_{12} \sim \mathrm{C}_{14}$ 体 の及測定の場合は $\left.2 \mathrm{~m} l \cdot \mathrm{min}^{-1}\right)$ に注入し，同族体・ 異性体 $(2 \phi, 3 \phi, 4 \phi, 5 \sim 7 \phi)$ 別に測定した。ピーク の同定と定量は同様の前処理を施した標準 LAS 溶液 の保持時間と面積比により行った。この前処理による 溶存 LAS の平均回収率は96.9土4.4\%(3 回)であっ た。

吸着 LASについては懸濁物から沪紙ごとメタノ一 ルで超音波抽出(30分)した後, メタノール相に2 倍量 の純水と $0.2 \mathrm{~mol} ・ l^{-1}$ となるように塩化カリウムを加 えた後 MIBK に抽出し, 以下同様に n-ヘキサンを加 えて水相に逆抽出した試料を HPLCで測定した。現場 の底質サンプルを用いて, 吸着 LAS についての添加 回収実験を行った結果, 平均回収率は100.5土2.8\%(3 回)であった。

\section{4.結果}

\section{1 河川および湖沼における LAS 濃度}

3 つの調査地点（st. 1 , st. 2 , st. 3 ) に抢ける 1 年 間12回（月 1 回）の調査結果から, 各地点の懸濁物濃 度, 懸濁物中の有機炭素含量, 溶存 LAS 濃度, 懸濁物 への吸着 LAS 濃度の值の範囲をTable 2 に示す。 LAS 濃度は夏に低く冬に高い傾向があり, 河川ではそ の差はせいぜい数倍程度だったが湖沼では $2 \sim 3$ オー ダーの範囲で季節変動を示した。また, 全 LAS 濃度に 占める溶存態の割合は年間を通して 7 割以上であっ た。

\section{2 実験による吸着特性の変化}

\subsubsection{LAS 同族体・異性体 (run 1)}

吸着媒は湖沼底質 (st. 2 の表層底質), 吸着媒濃度は $100 \mathrm{mg} \cdot l^{-1}$ の条件で $\mathrm{C}_{12}, \mathrm{C}_{13}, \mathrm{C}_{14}$ の各体 LAS の混合 物（組成比 $1: 1: 1$ ) を吸着質とした吸着実験結果を同 族体（各々複数の異性体の合計）別の吸着関係（吸着 LAS 濃度と溶存濃度の関係) として Fig. 2 に示す。ま た, 吸着媒粒子の種類と濃度を変化させた 6 通り(run 1〜6）の実験データから最小自乗法により計算され た $k$ の值の $\mathrm{C}_{12}$ と $\mathrm{C}_{13}$ の各異性体別の分布を Fig. 3 に 示す。これらの結果は, 長鎖同族体ほど LAS が吸着し

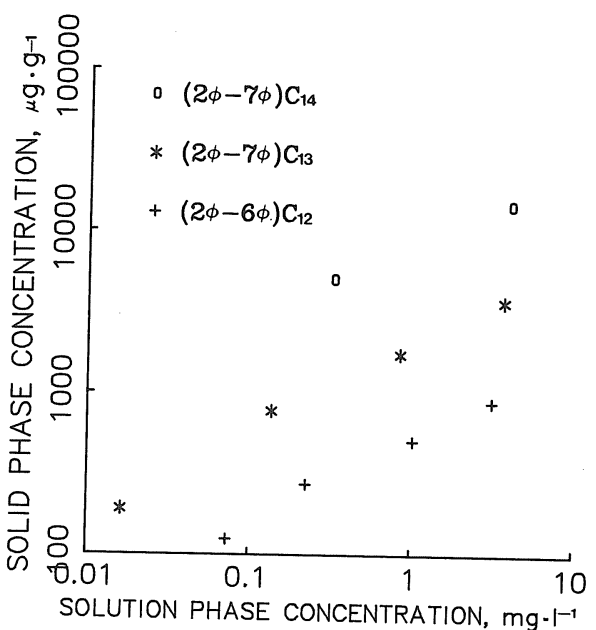

Fig. 2 Adsorption isotherms for LAS homologues on the lake sediments.

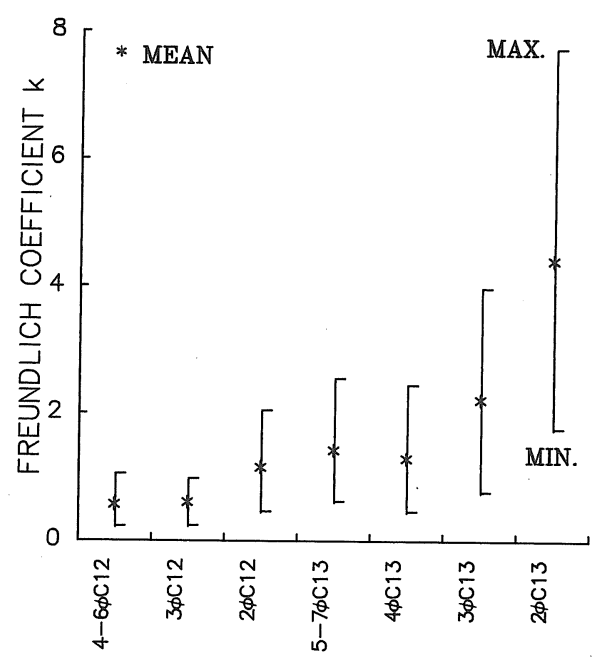

Fig. 3 Freundlich coefficient $k$ of each LAS isomer.

やすく, 同じ同族体でもベンゼン環の置換位置がアル キル鎖の末端に近いほど吸着しやすいというこれまで の知見を裏づけている。しかし，Fig.3に示す通り異 性体間での吸着の違いについて $2 \phi$ 体と $3 \phi$ 体以上で は明らかであったが，3申体以上については大きな差 
Table 3 Values of the Freundlich coefficient $k$ and $n$, which are the results of the LAS adsorption experiments.

\begin{tabular}{|c|c|c|c|c|c|c|c|c|c|}
\hline \multicolumn{2}{|c|}{ experimental conditions } & \multicolumn{2}{|c|}{$(3 \phi-6 \phi) C_{12}$} & \multicolumn{2}{|c|}{$\mathrm{k}^{2 \phi \mathrm{C}_{12}}$} & \multicolumn{2}{|c|}{$(3 \phi-7 \phi) C_{13}$} & \multicolumn{2}{|c|}{$2 \phi \mathrm{C}_{13}$} \\
\hline & 0.08 run 1 & 1.35 & 1.92 & 2.02 & 1.76 & 4.36 & 1.66 & 7.70 & 1.41 \\
\hline & 0.16 run 2 & 1.38 & 2.36 & 1.82 & 2.16 & 4.25 & 2.15 & 5.56 & 2.59 \\
\hline & 0.25 run 3 & 0.30 & 2.12 & 0.45 & 1.92 & 1.10 & 1.95 & 1.74 & 2.15 \\
\hline & 10 run 4 & 0.58 & 2.67 & 0.87 & 2.11 & 2.23 & 2.37 & 3.98 & 1.82 \\
\hline concentration & 50 run 5 & 0.71 & 2.14 & 1.11 & 1.91 & 2.76 & 1.98 & 4.98 & 1.69 \\
\hline & 1100 run1 & 0.30 & 2.12 & 0.45 & 1.92 & 1.10 & 1.95 & 1.74 & 2.15 \\
\hline & 1000 run6 & 0.36 & 1.75 & 0.57 & 1.55 & 1.24 & 1.60 & 2.41 & 1.50 \\
\hline & $0: 1: 0$ run 7 & - & - & - & 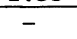 & 2.75 & 1.40 & 4.91 & 1.60 \\
\hline fraction 0 & $4: 1 \mathrm{ru}$ & 0.17 & 1.71 & 0.28 & 1.45 & 0.95 & 1.50 & 1.57 & 1.38 \\
\hline LAS h & $1: 1: 1 \mathrm{ru}$ & 0.30 & 2.1 & 0.45 & 1.9 & 1.10 & 1.95 & 1.74 & 2.15 \\
\hline$C_{12}: C_{13}: C_{14}$ & $4: 1: 1$ run 9 & 0.34 & 1.53 & 0.53 & 1.38 & 0.78 & 1.30 & 1.47 & 1.22 \\
\hline & $1: 0: 0$ run 10 & 1.07 & 1.46 & 1.86 & 1.40 & - & - & - & - \\
\hline & & 0.29 & 1.34 & 0.62 & 1.07 & 0.88 & 1.00 & & \\
\hline temperature ${ }^{\circ} \mathrm{C}$ & & 0.38 & 1.2 & 0.78 & 1.31 & 1.09 & 1.60 & - & - \\
\hline & $25 \mathrm{rr}$ & 0.34 & 0.92 & 0.80 & $\frac{1.02}{1.02}$ & $\frac{1.14}{1.14}$ & $\frac{0.92}{0.92}$ & - & $\frac{-}{-}$ \\
\hline & $\begin{aligned} 0 & \text { rur } \\
100 & \text { rur }\end{aligned}$ & & $\begin{array}{l}0.92 \\
1.50\end{array}$ & $\begin{array}{l}0 . \\
0 .\end{array}$ & & & & - & \\
\hline of $\mathrm{KCl} \mathrm{mg} \cdot 1^{-1}$ & $200 \mathrm{ru}$ & 0.40 & 1.27 & 0.64 & 1.23 & 1.27 & 0.82 & - & - \\
\hline & 500 run16 & & 1.11 & & & 1.42 & 0.86 & & \\
\hline
\end{tabular}

が認められなかったため, 以後本研究では異性体につ いて各同族体ごとに $2 \phi$ 体と $3 \phi$ 体以上の合計という 2 種類に分けて考察する。

吸着実験の結果を各条件(run)ごとに Freundlich 式((1)式)にあてはめて, 最小自乗法により求めた $k$ とnの值を Table 3 に示す。 $\mathrm{C}_{14}$ 体については低濃度側 で溶存濃度が検出限界以下となることが多くケース数 が少ないため，計算は行わなかった。 $\mathrm{C}_{12}$ 体と $\mathrm{C}_{13}$ 体に ついては，前述のようにそれぞれ 2 種類の異性体に分 けて, 全部で 4 種頑の異性体を対象とした。以後この 4 種のLAS異性体, 寸なわち $(3 \phi \sim 6 \phi) \mathrm{C}_{12}, 2 \phi \mathrm{C}_{12}$, $(3 \phi \sim 7 \phi) \mathrm{C}_{13}, 2 \phi \mathrm{C}_{13}$ 多 4 種の LAS 成分之記す。

\section{2 .2 吸着媒の種類（run $1,2,3$ ）}

吸着媒濃度は $100 \mathrm{mg} \cdot l^{-1}$, 吸着質は混合 $\operatorname{LAS}\left(\mathrm{C}_{12}\right.$ : $\mathrm{C}_{13}: \mathrm{C}_{14}=1: 1: 1$ )の条件で, 吸着媒は湖沼底質 (lake sediments), 湖沼水中懸濁物 (lake solids), 河川水中 懸濁物（river solids）を用いた吸着実験の結果を，吸 着媒ごとの $\mathrm{C}_{12}$ 体 LAS の吸着関係として Fig. 4 亿示 す。LAS は湖沼底質よりも河川括よび湖沼の水中懸濁 物の方に吸着しやすい傾向があった。吸着媒粒子の有 機炭素含量は重量比で河川水中懸濁物が 0.25 , 湖沼水 中懸濁物が 0.16 , 湖沼底質が 0.08 であり, 有機炭素含 量の高い吸着媒汪ど LAS が吸着しやすいものと推定 された。

\subsection{3 吸着媒の濃度 (run 1, 4, 5, 6)}

吸着媒は湖沼底質, 吸着質は混合 $\operatorname{LAS}\left(\mathrm{C}_{12}: \mathrm{C}_{13}\right.$ : $\left.\mathrm{C}_{14}=1: 1: 1\right)$ の条件で, 吸着媒の濃度を $10,50,100$, $1000 \mathrm{mg} \cdot l^{-1}$ 之変化させた実験結果を吸着媒濃度別の $\mathrm{C}_{12}$ 体 LAS の吸着関係として Fig.5 に示す。図より, 吸着媒濃度が50 mg・ $l^{-1}$ 以下の場合に比べて $100 \mathrm{mg} ・$

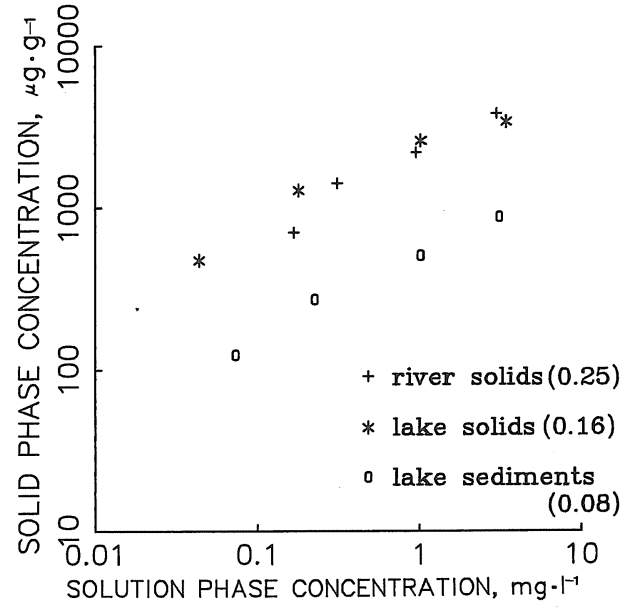

Fig. 4 Adsorption isotherms for $\mathrm{C}_{12}$-LAS on various adsorbent. The values in parenthesis show the fractional organic carbon content.

$l^{-1}$ 以上の場合では, LAS の分配はょり溶存相に偏っ ていることがわかる。

\subsubsection{LAS の成分比（run 1, $7 \sim 10 ）$}

吸着媒は湖沼底質, 吸着媒濃度は $100 \mathrm{mg} \cdot l^{-1}$, 吸着 質は混合 LAS の条件で，吸着質の LAS 同族体 $\left(\mathrm{C}_{12}\right.$ $\sim \mathrm{C}_{14}$ ) の組成比を変化（初期濃度の組成比は Table 1 参照)させる実験を行った。各体 LAS の成分比は溶存 態・吸着態を合わせた全 LAS 濃度で計算した。( $3 \phi \sim 6$ ф) $\mathrm{C}_{12}$ 体 LAS を例として, 全 LAS $\left(\mathrm{C}_{12} \sim \mathrm{C}_{14}\right)$ 中に 占める成分比 (fraction of isomer) 別の吸着関係 ( (3 $\phi \sim 6 \phi) \mathrm{C}_{12}$ 体 LAS の溶存濃度と吸着濃度の関係) を Fig. 6 に示す。成分比により吸着特性が変化し, 成分 


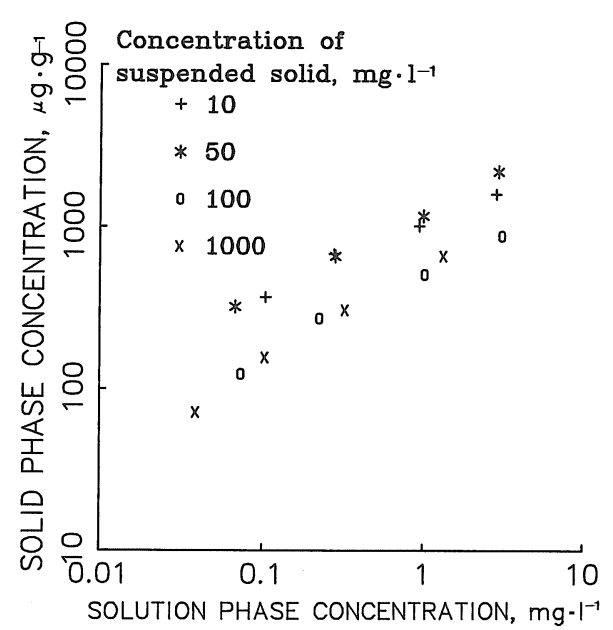

Fig. 5 Adsorption isotherms for $\mathrm{C}_{12}$ - LAS on the lake sediments : effect of the solids concentration.

比が高いほど吸着しやすい傾向があった。

4.2 .5 水中の温度および電解質濃度（run11〜16）

温度扣よび電解質濃度ともに現場の水域における変 動範囲では，LASの吸着特性には汪とんど影響しな かった (Table 3)。

\section{5. 考察}

\subsection{Freundlich 定数 $k$ の変動}

Table 3 より $k$ の值は明らかにLAS 分子のアルキ ル基の直鎖の長さが長いほど大きい。アルキル基の長 さと $k$ の值との関係については同様の結果を示す報 告4),6),10) 12) も多い。水中懸濁物や底質への LAS の吸着 が主に LAS 分子の疎水基 (アルキル基)による吸着で あり,「吸着のしやすさ」はLAS の疎水性に依存する とされている。

多くの疎水性有機化合物 (hydrophobic compounds）の分配係数が対象物質のオクタノール/水分 配係数の関数として計算されたように ${ }^{13)}$, LASについ ても同族体・異性体ごとに基本となる $k$ の值があり, 現場の河川・湖沼水中では吸着媒である懸濁物質や水 の特性により基本值から変動することが予想される。 前述したように, 温度と水中の電解質濃度については 現場の条件では LAS の吸着にほとんど影響がなかっ た。そこで, 現場に和ける LAS の吸着に影響する因子 として, 懸濁物の有機炭素含量と懸濁物濃度, さらに 溶存態と吸着態を合わせた全同族体・異性体 LAS に 占める対象 LAS 成分（同様に溶存態・吸着態の合計） の成分比に着目し, Freundlich 式に拈ける $k$ の值とこ れらの関係について考察する。

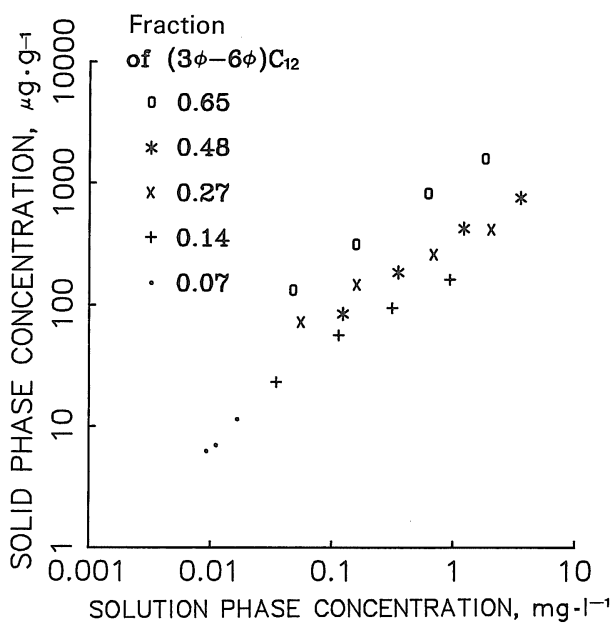

Fig. 6 Adsorption isotherms for $(3 \phi-6 \phi) \mathrm{C}_{12}$-LAS on the lake sediments : effect of the fraction of isomer.

\section{2 懸濁物の有機炭素含量と $k$}

いくつかの疎水性化合物について，水一懸濁物間の 分配が懸濁粒子の有機炭素含量 $f_{o c}$ と関係することが Karickhoff ら ${ }^{13)} \mathrm{O}^{\prime}$ Connor $ら^{14)} に よ り$ 報告されて おり

$$
\begin{aligned}
& k=k_{a 0} \bullet f_{o c} \\
& \text { ただし, } k_{a 0} \text { : 吸着質ごとに異なる定数 }
\end{aligned}
$$

といら関係式が提示されている。Fig.7に示すと拈り, LASについても $k$ が各成分ごとに懸濁物の有機炭素 含量に比例して変化していることが確認された。ただ 乙, 今回の実験は懸濁物の種類が 3 通り $\left(f_{o c}=0.25\right.$, 0.16，0.08）しかなく, 若干のばらつさがあった。

Hand ${ }^{11)}$ の実験では, LASの吸着と吸着媒の有機 炭素含量の間には相関がみられなかったが, Matthijs $ら^{10)}, U r a n o 5^{9)}$ 実験では相関が認められている。 それぞれ用いた吸着媒の有機炭素含量は0.009〜0.035 (Handら), 0.0034〜0.0341(Mtthijsら), 0.007〜0.06 (Urano ら)であり, 本研究の吸着実験と比較して吸着 媒の有機炭素含量の変動範囲が小さかった。LAS の懸 濁物への吸着が主に蹯水基による吸着であることから も, 他の疎水性化合物と同様に LAS の吸着が吸着媒 の有機炭素含量と関係があると考学ることが妥当であ る。

実験結果を各成分ごとに(6)式にあてはめた場合, $k_{a 0}$ の值は LAS 成分のアルキル基の直鎖の長さが長い 㴗ど大さくなった。

\section{3 懸濁物濃度と $k$}

O'connor $5^{14)}$ は疎水性化合物の水〜懸濁物間の分 配が水中の懸濁物濃度にも影響されることを指摘し, 


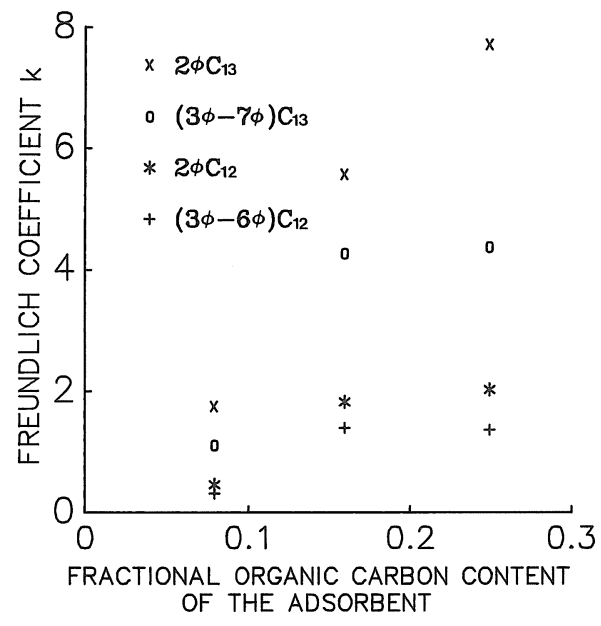

Fig. 7 Freundlich coefficient $k$ of each LAS component as a function of the fractional organic carbon content.

その関係を懸濁物濃度が $10 〜 10,000 \mathrm{mg} \cdot l^{-1}$ の範囲で は次式で表している。

$$
\begin{aligned}
& k=k_{b 0} / S^{\alpha} \\
& \text { ただし }, k_{b 0} \text { : 吸着質ごとに異なる定数 } \\
& S: \text { 懸濁物濃度 }\left(\mathrm{mg} \cdot l^{-1}\right) \\
& \alpha: \text { 懸濁物濃度の効果の大きさを表す係 } \\
& \quad \text { 数 }
\end{aligned}
$$

懸濁物濃度のみを変化させた今回の吸着実験の結果か ら， $k$ と懸濁物濃度の関係を Fig. 8 亿示す。懸濁物濃 度が高い領域 (100 $\mathrm{mg} \cdot l^{-1}$ 以上) の方が低い領域 (50 $\mathrm{mg} \cdot l^{-1}$ 以下) に比べて $k$ の值が小さいことが明らかで ある。

本研究では, 現地調査, 室内吸着実験いずれにおい ても「懸濁物吸着態の LAS」として測定したのは平均 保持能力 $1.2 \mu \mathrm{m}$ の沪紙を通過しなかった粒子に吸着 していた LAS であり，この沪紙を通過した微粒子に 吸着した LAS は溶存態として測定されている。した がって, Gschwend ら ${ }^{18)}$ が指摘したように, 懸濁物濃度 の増加による $k$ の值の低下は固液分離上の問題に由 来するものと思われる。今回はあくまで現場の吸着特 性を説明することを目的として，現場と同じ条件の実 験から得られた結果をそのまま利用して考察する。

データ数が少なくばらついているが, 実験結果を(7) 式にあてはめると， $k_{b 0}$ の值が，やはり対象成分のアル キル基の直鎖の長さが長い汪ど大きかった。

\section{4 対象 LAS 成分の成分比と $k$}

水中有機成分の活性炭による吸着除去の際に吸着質 が多成分の場合, 競合吸着平衡の考方方が必要になっ

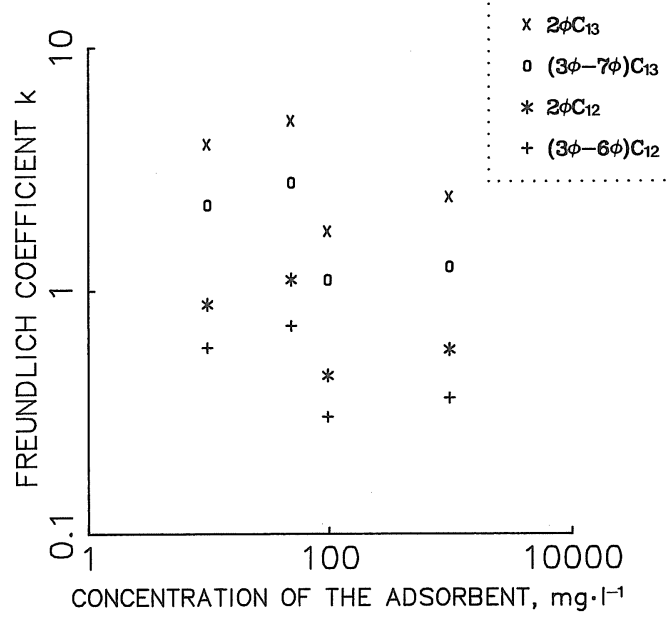

Fig. 8 Freundlich coefficient $k$ of each LAS component as a function of the solids concentration.

ており，単成分系に和ける特定成分の吸着量が多成分 系では低下していることが観測されている19)。

本研究では，溶存 LAS の初期濃度の組成比のみを 変化させて $k$ の值の変化を調べたが，吸着媒として用 いた現場の底質・懸濁物粒子には，もともと多種多様 の化合物が吸着していたものと考党られ，多成分系の 吸着について LAS のみの組成変動だけで一般的な議 論はできないと思われる。ここでは，LASの同族体・ 異性体間での競合吸着についてのみ検討を行った。

Fig. 9 に示すとおり, 吸着媒である懸濁物の種類, 濃度ともに一定の条件で, 4 種の LAS 成分ごとの $k$ の值は全 $\operatorname{LAS}\left(\mathrm{C}_{12}, \mathrm{C}_{13}, \mathrm{C}_{14}\right.$ の合計)に拉ける各成分 の成分比 (fraction) が大きい汪ど大きくなる傾向があ $\eta, k$ 上成分比之の関係は，

$$
\begin{aligned}
k=k_{c 0} \bullet r^{\beta} & \\
\text { ただし, } & k_{c 0} \text { : 吸着質ごとに異なる定数 } \\
& r \text { : 対象成分の存在比 } \\
& \beta \text { : 存在比の効果の大きさを表す係数 }
\end{aligned}
$$

といら非線型の式で表されることが予想された。実験 結果を(8)式にあてはめると, $k_{c 0}$ は前述の $k_{a 0}, k_{b 0}$ と同 様にアルキル基の直鎖の長さが長い葟ど大きかった。

\section{5 吸着におよぼす $\mathrm{pH}$ の影響}

吸着実験に拈ける，溶液中の $\mathrm{pH}$ は5.5〜6.5の範囲 であった。吉村ら ${ }^{6)}$ は $\mathrm{pH} 6$ 以下の酸性領域で懸濁粒 子表面の負電荷が減少するために LAS 吸着量が増加 するとしているが，こ机に対して山本ら吸着媒と して用いた Kerogen（堆積高分子有機物）がアルカリ 性領域で負電荷どらしの反発から膨潤を起こして表面 


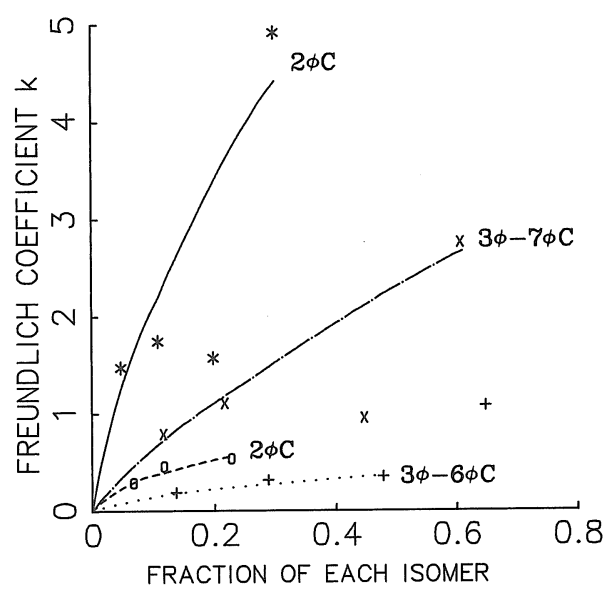

Fig. 9 Freundlich coefficient $k$ of each LAS component as a function of the fraction of isomer.

積が大きくなり, ABS の吸着量が酸性領域よりも増大 することを報告している。

LAS は疎水基をもった電解質であり, その物理化学 的な挙動は当然 $\mathrm{pH}$ の影響を受けることが予想される が, 吸着に対する $\mathrm{pH}$ の影響には吸着媒の表面状態, 溶 存 LAS の初期濃度や, $\mathrm{pH}$ 調整のため用いた緩衝液の 存在など多くの要因が関係していると考党られる。こ れまでの知見 ${ }^{5,6)}$ から pH5.5 6.5に打ける吸着量の 変動は10 20\%程度であり, Table 3 亿示す通り今回 の 3 通りの要因 (吸着媒の有機炭素含量, 吸着媒の濃 度, 対象 LAS 異性体成分比) に上る吸着量の変動に比 べて小さいため, 本研究では $\mathrm{pH}$ の影響については検 討しなかった。

\subsection{Freundlich 式中の傾き $n$}

Hand $ら^{11}$ は $\mathrm{C}_{10}$ と $\mathrm{C}_{14}$ の LAS 同族体について溶存 LAS の初期濃度 $0.01,0.1,1 \mathrm{mg} \cdot l^{-1}$ の 3 点による平 衡吸着関係が線型 $(n=1)$ になるとしている。 $n$ の值 は1よりも大きいといら結果5),7) 10)が多いが，これら は LAS の初期濃度が高い( $\left.5 \sim 40,10 \sim 1000 \mathrm{mg} \cdot l^{-1}\right)$ 条件で行われている。しかし, Matthijs ら ${ }^{10)}$ は初期濃 度 $0.25,1,2.5,5,15 \mathrm{mg} \cdot l^{-1}$ といら比較的低濃度 の条件を含む吸着実験でも、いくつかの吸着媒（河川 底質）について 1 よりも大きいnの值を報告してい る。

本研究の吸着実験で得られた nの值はいずれの条 件に执いても 1 より大きく, 初期濃度が低い条件を含 むにもかかわらず, Hand らの結果と異なっている。こ れは，今回用いた吸着媒が污染のかなり進行した水域 の底質掞よび懸濁物であったこと, 初期濃度の範囲が 比較的広かったことなどが原因であったと考学られ
る。

現地調査で得られた水中の溶存 LAS 濃度と懸濁物 中の LAS 吸着量の一対のデータを用いて Freundlich 式に拉ける $k$ を計算するためには, 現場の $n$ の值を決 める必要がある。同じ現場の底質・懸濁物を用いた吸 着実験による異性体別の $n$ の平均值は1.60 1.75の 範囲だったが, 実験で最も検出件数の多かった $(3 \phi \sim 6$

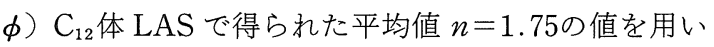
て現場の $k$ を計算した。

\subsection{Freundlich 定数 $k$ の推定と検証}

有機化合物の吸着に関するこれまでの知見と今回の 実験結果から, LAS の各成分ごとの懸濁物質への吸着 をFreundlich の等温吸着式にあてはめたときの $k$ の 值を，LAS 成分（同族体・異性体）ごとにもつ基本的 な定数に, 懸濁物の有機炭素含量, 懸濁物濃度, 対象 LAS 成分の全 LAS に対する成分比といら 3 つの变数 の関数を乗じた式で表す。

$$
k=k_{0} \cdot F\left(f_{o c}, S, r\right)
$$

関数 $F$ の形式については, 個々の因子との関係式を組 み合わせると,

$$
k=k_{0} \cdot f_{o c} \cdot r^{\beta} / S^{\alpha}
$$

ただし， $k_{0}$ ：LAS の成分ごとに異なる定数

$f_{o c}:$ 懸濁物の有機炭素含量（重量比）

$S:$ 懸濁物濃度 $\left(\mathrm{mg} \cdot \mathrm{l}^{-1}\right)$

$\alpha:$ 懸濁物濃度の効果の大きさを表す係数

$r$ : 対象 LAS 成分の全 LAS に対する成 分比

$\beta$ : 成分比の効果の大きさを表す係数

といら形となる。 $k_{0}, \alpha, \beta$ を求める手順は以下のよう になる。

(1)吸着媒の種類のみを变化させた実験結果 (Fig. 7)を

(6)式にあてはめて，最小自乗法により

$$
k_{a 0}=k_{0} \cdot r^{\beta} / S^{\alpha}
$$

を 4 種の LAS 成分ごとに計算する。

(2)吸着媒濃度のみを変化させた実験結果（Fig.8）を

（7)式にあてはめて，最小自乗法により

$$
k_{b 0}=k_{0} \cdot f_{o c} \cdot r^{\beta}
$$

と $\alpha$ を 4 種の LAS 成分ごとに計算する。

(3) LAS 異性体の成分比（fraction）のみを変化させた 実験結果（Fig.9）を（8）式にあてはめて，最小自乗 法により

$$
k_{c 0}=k_{0} \cdot f_{o c} / S^{\alpha}
$$

と $\beta$ を 4 種の LAS 成分ごとに計算する。

(4) (11) （13)式にそれぞれの実験に和ける統一条件 ( $f_{o c}, r, S$ の值) と最小自乗法により計算された $\alpha$, $\beta$ を代入して，各実験別の $k_{0} を 4$ 種の LAS 成分ご とに求める。 
(4)で 3 通りの各実験ごとに求められた $k_{0}$ の值とそ の平均值, また(2)で求められた $\alpha$, 拈よび(3)で求めら れた $\beta$ の值を 4 種の LAS 成分ごとにTable 4 に示 す。各実験ごとの最小自乗法の結果得られた相関係数 も付記してある。要因 2 （懸濁物濃度のみの効果）に 打けるあてはめのときの相関係数が小さいが，基本值 である平均 $k_{0}$ の值は LAS 成分のアルキル基の蹯水性 に関係した結果が得られた。

このようにして得られた平均 $k_{0}, \alpha, \beta$ の值による (10)式の検証を4.1で示した現地データを用いて行っ た。現地調查のデータから実測の $k$ を求める場合は, 5.6で述べたように Freundlich 式で $n=1.75$ として計 算した。また, 溶存態・吸着態を合わせた $\mathrm{C}_{11} \sim \mathrm{C}_{14}$ 体 LAS 濃度の合計を全 LAS とし, 現地の LAS 成分比 はこの全LAS に対する対象成分の比として計算し た。

$k$ の実測值と推定値の関係を 4 種のLAS成分別に
Fig. 10 亿示す。実測值と推定値の相関係数は 0.63 〜0.87の範囲であった。全体としては，推定值と実測 値はよく適合していたが, $\mathrm{C}_{13}$ 体の推定值がやや高めの 傾向を示した。この理由としては，現場の水中では LAS 以外の多くの吸着質との競合効果もあること，ま た, 現場の $\mathrm{pH}$ の変動範囲が $7 \sim 9$ で実験条件よりる やや高めであったことなどが考兄れる。

現場に打ける実測の $k$ と懸濁物の有機炭素含量, 懸 濁物濃度との関係は Fig. 11 と Fig. 12 亿示すと拉り, 実験結果と同様の傾向を示した。

\section{6.おわりに}

現地調査により河川和よび湖沼水中の LAS の溶存 態濃度と懸濁物吸着濃度の関係を観測した結果, 現地 データをFreundlich の等温吸着式にあてはめたとき の $k$ の值がいくつかの外的要因によって変動するこ とが予想された。

Table 4 Parameters used to predict the Freundlich coefficient $k$ of LAS in the river and the lake water.

\begin{tabular}{|c|c|c|c|c|}
\hline parameter & $(3 \phi-6 \phi) C_{12}$ & $2 \phi \mathrm{C}_{12}$ & $(3 \phi-7 \phi) \mathrm{C}_{13}$ & $2 \phi \mathrm{C}_{13}$ \\
\hline \begin{tabular}{|ll} 
FACTOR1* & $\mathrm{k}_{0}$ \\
(correlation & coefficient) \\
\end{tabular} & $\begin{array}{c}28.1 \\
(0.84) \\
\end{array}$ & $\begin{array}{c}49.3 \\
(0.90)\end{array}$ & $\begin{array}{l}129.7 \\
(0.86)\end{array}$ & $\begin{array}{l}273.2 \\
(0.98)\end{array}$ \\
\hline $\begin{array}{cc}\text { FACTOR2 }{ }^{* * *} \quad \mathrm{k}_{0} \\
\quad a \\
\text { (correlation coefficient) }\end{array}$ & $\begin{array}{c}24.0 \\
0.13 \\
(0.49) \\
\end{array}$ & $\begin{array}{c}47.9 \\
0.12 \\
(0.45) \\
\end{array}$ & $\begin{array}{c}138.9 \\
0.15 \\
(0.54)\end{array}$ & $\begin{array}{c}317.0 \\
0.14 \\
(0.44) \\
\end{array}$ \\
\hline $\begin{array}{cc}\text { FACTOR3***** } & \mathrm{k}_{0} \\
& \beta \\
\text { (correlation } & \text { coefficient) } \\
\end{array}$ & $\begin{array}{l}12.5 \\
0.57 \\
(0.94) \\
\end{array}$ & $\begin{array}{c}26.5 \\
0.53 \\
(0.92) \\
\end{array}$ & $\begin{array}{l}98.0 \\
0.79 \\
(0.99) \\
\end{array}$ & $\begin{array}{r}238.4 \\
0.69 \\
(0.99) \\
\end{array}$ \\
\hline AVERAGE & 21.5 & 41.2 & 122.2 & 276.2 \\
\hline
\end{tabular}

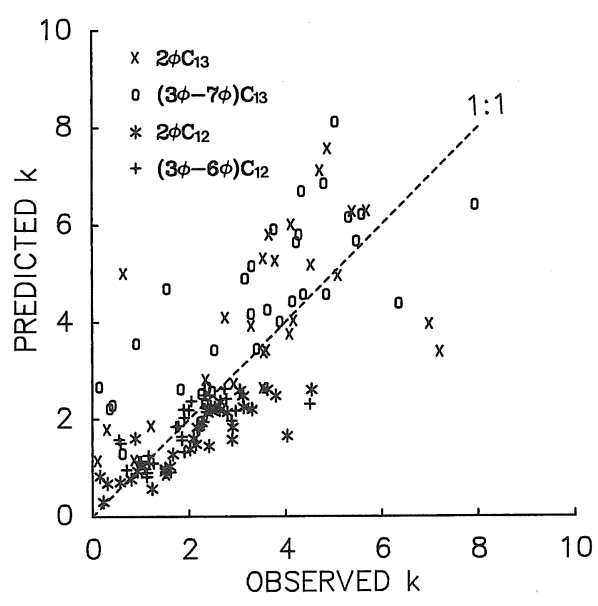

Fig. 10 Relationships between the predicted and the observed Freundlich coefficient $k$ of each LAS component.

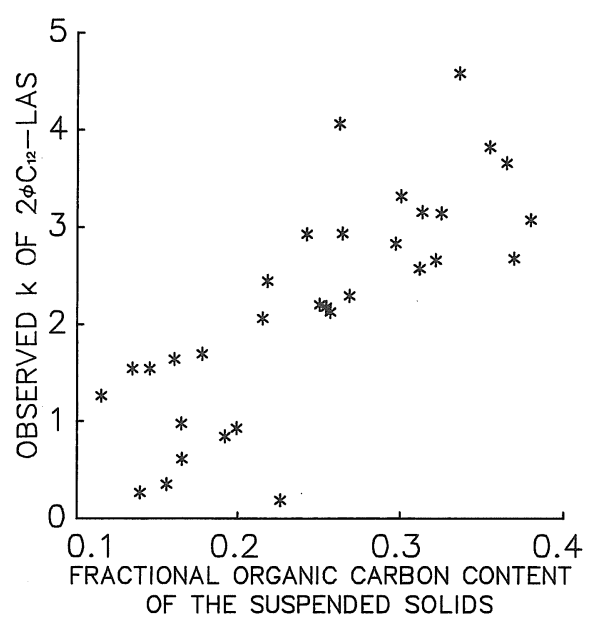

Fig. 11 Relationships between the Freundlich coefficient $k$ of $2 \phi \mathrm{C}_{12}$-LAS and the fractional organic carbon content in suspended solids in the river and the lake water. 


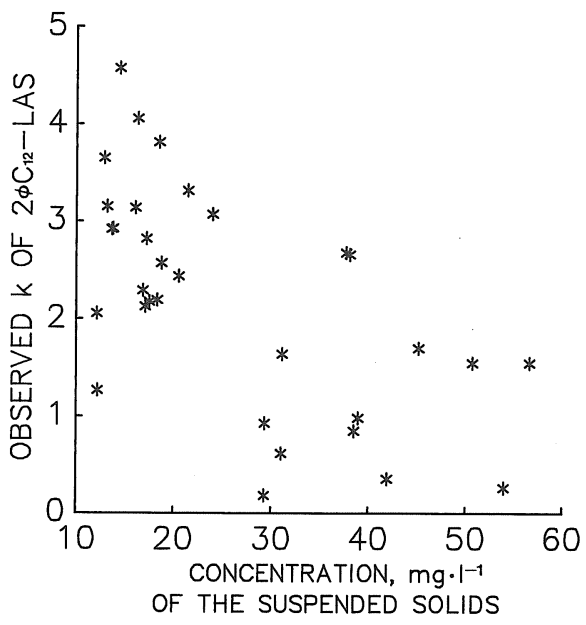

Fig. 12 Relationships between the Freundlich coefficient $k$ of $2 \phi \mathrm{C}_{12}$-LAS and the suspended solids concentration in the river and the lake water.

現地で採取した懸濁物および底質を用いて行った吸 着実験で，kの值の変動と吸着媒(懸濁物)の有機炭素 含量, 吸着媒 (懸濁物) 濃度, さらに対象 LAS 成分の 成分比 (fraction) の変動との関係を確認した。実験結 果から求めた $k$ の推定式を現場のデータを用いて検 証した結果, 河川执よび湖沼水中の $k$ の推定值と実測 値はよく適合していた。

今後は, LAS 以外の吸着質による競合吸着の効果や $\mathrm{pH}$ の影響も考慮した LAS の分配 (溶存一吸着) の定 式化を検討する必要がある。また，このような分配理 論を現場に適用することによって，より現場に即した LAS の運命予測手法の開発が可能になるものと考光 られる。

（原稿受理 1989年 4 月14日）

\section{引用 文 献}

1) 化学工業日報社 (1988)化学工業年鑑昭和63年版, $386 \mathrm{pp}$.

2) A.D. Little, Inc (1981)界面活性剂の科学, 米国石䲓洗剂工業 会報告書 (黒沢幸雄監訳), $35 \mathrm{pp}$.

3 ) 天野耕二, 福島武彦(1989)全国湖沼底質中の直鎖アルキルヘ ンゼンスルホン酸塩 (LAS) の分布特性, 衛生工学研究論文集, 25, 59-68.

4 ) 本波裕美, 山本修一, 半谷高久 (1979)水環境中に括ける ABS の組成変化, 地球化学, 13, 51-55,

5 ) 山本修一, 石渡良志, 本波裕美(1981)水環境に扣ける堆積高
分子有機物 (Kerogen) と ABS との相互作用, 水質污濁研究, 4, 65-72.

6) 吉村孝一, 中栄篤男(1982)活性污泥による直鎖アルキルベン ゼンスルホン酸ナトリウム (LAS) の生分解性に関する研究 (I) -LAS の吸着機構について, 水質污濁研究, 5, 19-25.

7 ）伏脇裕一, 田中克彦, 浦野紘平 (1982)界面活性剂の粘土鉱物 への吸着性, 水質污濁研究，5，151-159.

8 ) K. Urano and M. Saito (1984) Adsorption of Surfactants on Microbiologies., Chemosphere,13,285-292.

9) K. Urano, M. Saito and C. Murata (1984) Adsorption of Surfactants on Sediments., Chemosphere, 13, 293-300.

10) E. Matthijs and H.De Henau (1985) Adsorption and Desorption of LAS., Tenside Detergents, 22, 299-304.

11) V.C. Hand and G.K. Williams (1987) Structure-Activity Relationships for Sorption of Linear Alkylbenzenesulfonates., Environ. Sci. Technol., 21, 370-373.

12）古武家善成(1988)河川環境における直鎖アルキルベンゼン スルホン酸塩 (LAS) の生分解と吸着一兵庫県内明石川水系での 事例-, 陸水学雑誌, 49, 27-36.

13) S.W. Karickhoff, D.S. Brown and T.A. Scott (1979) Sorption of Hydrophobic Pollutants on Natural Sediments., Water Research, 13, 241-248.

14) D.J. O'Connor and J.P.Connolly (1980) The Effect of concentration of Adsorbing Solids on the Partition coefficient., Water Research, 14, 1517-1523.

15) T.C. Voice, C.P. Rice and W.J. Weber, Jr. (1983) Effect of Solids Concentration on the Sorptive Partitioning of Hydrophobic Pollutants in Aquatic Systems., Environ. Sci. Technol., 17, 513-518.

16) W.J. Weber, Jr. (1972) Physicochemical Processes for Water Quality Control, 640pp. Wiley-Interscience, New York.

17）高田秀重, 石渡良志(1988)多摩川（調布堰）河川水中の直鎖 アルキルベンゼンスルホン酸塩 (LAS)の挙動, 水質污濁研究, 11, 569-576.

18) P.M. Gschwend and S. Wu (1985) On the Constancy of Sediment-Water Partition Coefficient of Hydrophobic Organic Pollutants., Environ. Sci. Technol., 19, 90-96.

19) J.C. Crittenden, P. Luft and D.W. Hand (1985) Prediction of Multicomponent Adsorption Equilibria in Background Mixtures of Unknown Composition., Water Research, 19, 1537-1548.

20）千葉県水質保全研究所 (1984)手賀沼の底質一污染泥の堆積 と性状一, 水保研試料 No.39, 4 pp.

21) K. Inaba and K. Amano (1989) HPLC Determination of Linear Alkylbenzenesulfonate (LAS) in Aquatic Environment. Seasonal Changes in LAS Concentration in Polluted Lake Water and Sediment. Intern. J. Environ. Anal. Chem., 34, 203-213. 


\section{論文要旨}

\section{土地利用の異なる流域からの年間流出負荷量の大きさと変化}

海老瀬 潜一*

* 国立公害研究所水質土壤環境部

〈水質污濁研究 Vol.12 No.8（1989） pp.497 505〉

流域の土地利用の異なる農耕地河川と市街地河川で, 多項目の毎週 1 回定時の流出負荷量調查を連続 2 年間 および 7 年扔いて 1 年間実施して, 年間流出負荷量を比較検討した。年間平均流量は年間降水量に比例せず, 調査当日を含む前 10 日間の影響降雨に左右され，平均的な年間降水量でのある調査頻度の年間平均流量が推定 できた。年間平均流出負荷量は農耕地河川では年間平均流量の増大に対して増加し，市街地河川では下水道普 及に伴い減少した。両河川で, 合成洗剤の無リン化による $\mathrm{PO}_{4}-\mathrm{P} や \mathrm{~T}-\mathrm{P}$ の減少と $\mathrm{NO}_{3}-\mathrm{N} や \mathrm{~T}-\mathrm{N}$ の増加が見 られた。 $\mathrm{NO}_{3}-\mathrm{N}$ や $\mathrm{T}-\mathrm{N}$ の増加や各態窒素の増加は, 降水負荷量の増加や食料等輸入量急増に伴ら廃棄物量増 加の寄与を指摘した。土地利用により山地，田園地，市街地流域に分けて，各流域の比流出負荷量を比較検討 し，共通的なベース負荷としての降水負荷量に対する位置づけにより，自然的および人為的な污濁負荷として 水質污濁改善の根拠を提供した。

直鎖アルキルベンゼンスルホン酸塩（LAS）の河川・湖沼水中懸濁物への吸着特性の变化とその要因に

ついて

天野 耕二* 福島 武彦* 稲葉 一穂* 中杉 修身*

* 国立公害研究所

〈水質污濁研究 Vol.12 No.8 (1989） pp.506 515〉

水環境に怙ける化学物質の運命予測を行う際に重要な要素となる溶存態・懸濁態の分配について，LAS の懸 濁物への吸着特性を対象として検討した。

室内吸着実験の結果, LAS 濃度を Freundlich の等温吸着式にあてはめたときの $k$ の值は、これまで報告さ れているように，同族体・異性体によって1〜2オーダー程度の変動を示したが，同じ異性体でも吸着媒（懸 濁物）の有機炭素含量, 吸着媒濃度, 多成分吸着に抢ける競合の効果などの要因により 1 オーダ一近い変動を 示した。

同族体・異性体ごとに, これらの要因を説明変数とする $k$ の予測式を立て, 河川・湖沼水中の LAS 濃度のデー タを Freundlich の等温吸着式 $(n=1.75)$ にあてはめたときの $k$ の值を現場の実測值として, 予測式の検証を

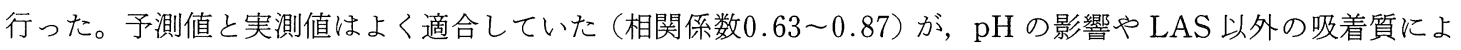
る競合吸着の効果も考慮する必要があることがわかった。

\section{電子衝撃および化学イオン化法による塩素化芳香族化合物の GC/MS 検出感度の比較}

益永 茂樹* 箓川 芳國* 米澤 義堯*

* 工業技術院公害資源研究所水環境保全部水処理生態研究室

〈水質污濁研究 Vol.12 No.8 （1989） pp.516～519〉 